\title{
THE CORPORATE REAL ESTATE MARKET IN PUBLIC STATISTICS IN POLAND
}

\author{
Jan Konowalczuk, PhD \\ Department of Investments and Real Estate \\ University of Economics in Katowice \\ e-mail: jan.konowalczuk@ue.katowice.pl
}

\begin{abstract}
This paper presents theoretical considerations regarding the needs and criteria of creating ownership divisions of real estate markets for the purpose of public surveys and research. The scope of necessary changes to the collection of information in public registers and institutional conditions is indicated, as a necessary aspect towards enabling separate studies for corporate real estate to be conducted. Study results comparing the basic parameters of the real estate market in the Silesian voivodeship (Silesia province) in 2004-2012, as per the Central Statistical Office (CSO) annual reports, are also presented, as are the results of an analysis of data collected from a database of appraisers and valuers. The market parameters adopted for comparison have in both cases been developed based on the same source data obtained from public documents of the Registers of Real Estate Prices and Values (RREPV). The article presents the detailed results of own research on the real estate market in the Silesian voivodeship for 2012, with regards to the amount of real estate, the transaction values, the area of properties, and selected averages with regards to property type in line with those used in CSO studies. Also included is an assessment of the completeness of the market data presented by the CSO, taking into account the selected types of real estate. This paper also indicates the results of a pilot survey study of office workers of the RREPV in poviat (district) council offices. The comparison of the regional real estate market forms a basis for the critical evaluation of the categories of real estate used in official statistics and selected forms of real estate turnover. Proposals regarding the needs and conditions that must be met in order to enable research on the corporate real estate market have also been formulated.
\end{abstract}

Key words: Corporate real estate (CRE), CRE market in Poland, real estate in public statistics.

JEL Classification: R30, D03, D70.

Citation: Konowalczuk J., 2014, The corporate real estate market in public statistics in Poland, Real Estate Management and Valuation, vol. 22, no. 2, s. 41-51.

DOI: 10.2478/remav-2014-0016

\section{Introduction}

In the emerging Polish real estate market, investors face difficulty in accessing reliable results of market analyses. This is particularly true in the corporate real estate (CRE) market (KONOWALCZUK 2009, pp. 52-54; KONOWALCZUK 2009a, pp. 86-101). Real estate market research collected by the Central Statistical Office (CSO) is therefore of great importance. One may only be in agreement with the view presented in literature that historical information regarding completed transactions is insufficient for the development of profitable investment strategies (KUCHARSKA-STASIAK 2006, p. 53). At the same time, it should be noted that restrictions with regards to information, or rather incorrect market information, intensifies a market's low effectiveness and therefore, the importance of the data obtained from available official statistics is extremely important.

The inspiration for this article was an analysis of data from the 2012 CSO report presenting the dynamics of sales transactions on the real estate market in Poland (Real estate turnover in 2012, 2013). 
The results of the report may suggest Poland is entering a phase of strong cyclical growth in this area. Figure 1 traces and illustrates the value of sales transactions on the Polish real estate market 2003-2012.

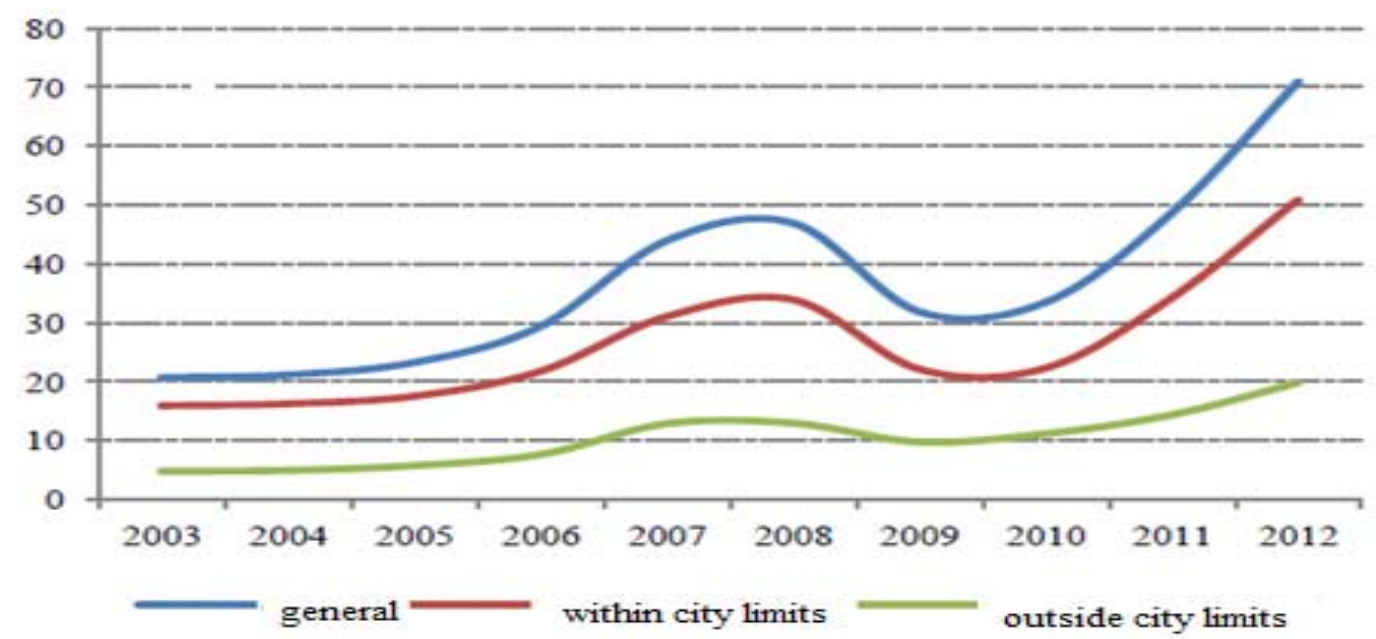

Fig. 1. The value of real estate sales transactions in Poland according to CSO research [billion PLN]. Source: REAL ESTATE TURNOVER IN 2012, p.12.

The author's own research findings with regards to the regional real estate market for the Silesian voivodeship (KONOWALCZUK, 2009a) suggest that there are differing characteristics regarding trends and dynamics of change on the market, particularly for the years 2011-2012. This can be traced by comparing the charts in Figures 1 and 2. The results of market research of the Silesian voivodeship can be considered as representative for the country as a whole, as the area accounts for approximately $10 \%$ of total market transactions (see: 23 YEARS OF THE POLISH REAL ESTATE MARKET 2013, p.10 and 27).

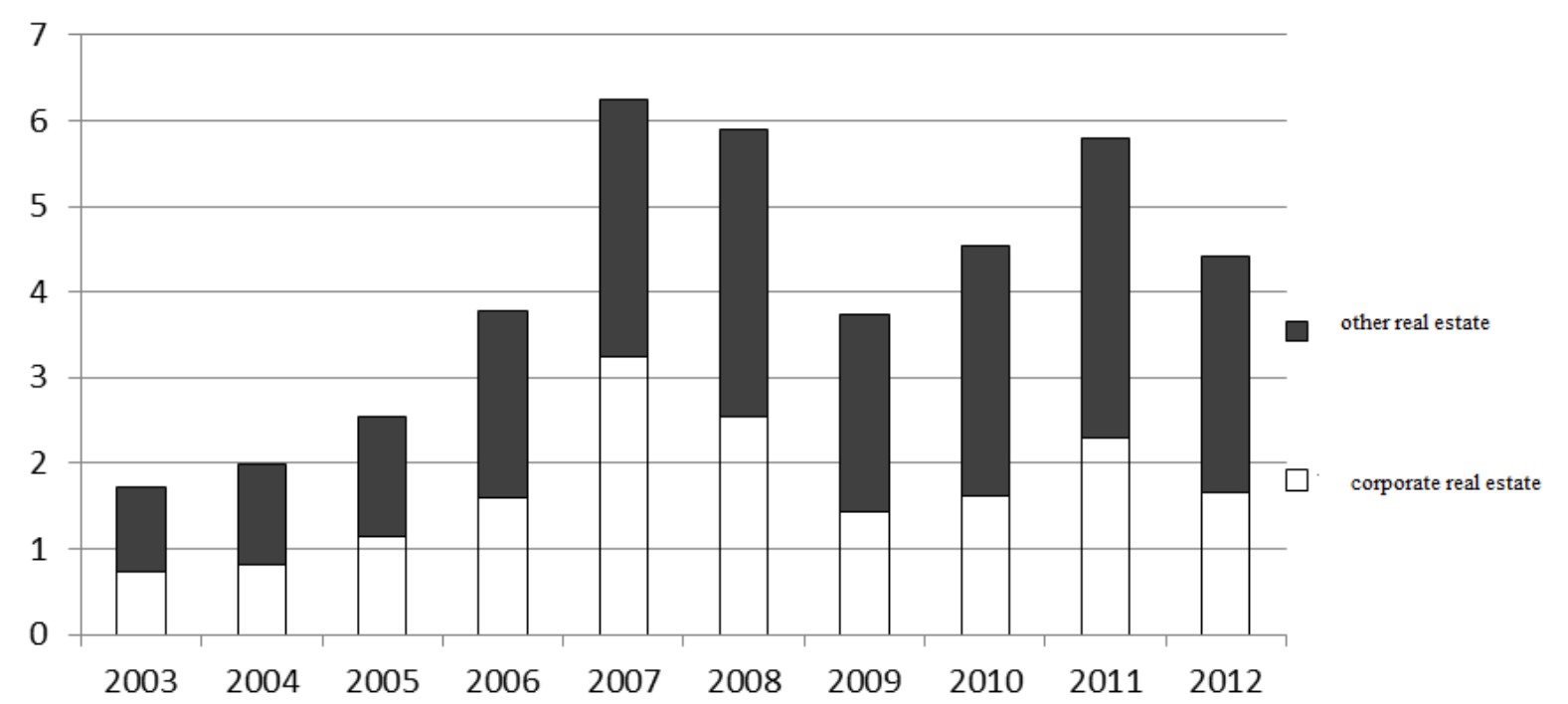

Fig. 2. The market value of real estate sales transactions in the Silesian voivodeship with a focus on the CRE market [billion PLN]. Source: own study.

The results of research on the real estate market in Poland, conducted on the basis of notarial deeds, indicate that in 2012, there was an overall 5\% decrease in activity on the Polish real estate market. The number of market transactions fell from a stable level of 452 thousand units recorded for the years 2010-2011 to 428 thousand units in 2012 (23 YEARS POLISH REAL ESTATE MARKET 2013, p.14). By 2012, the real estate market in Poland had not regained the maximum levels of activity of 2007, when 490 thousand transactions were performed (KAŁKOWSKI, 2010, p. 12). In this context, substantial doubts may be raised with regards to the increased value of sales transactions in the years 2011-2012 as recognized by the CSO. Table 1 summarizes the data from two independent sources of official statistics which relate to changes in the years 2007-2012 in terms of the number of notarial acts (the reports of notaries MS Not-24) and the value of property sales transactions recorded by the CSO (from M-04s reports). 
Table 1

Number, value and dynamics of real estate sale transactions in Poland 2007-2012; CSO transactions recorded by $\mathrm{CSO}$

\begin{tabular}{|c|c|c|c|c|c|c|}
\hline Details & 2007 & 2008 & 2009 & 2010 & 2011 & 2012 \\
\hline $\begin{array}{l}\text { (Total) Number of transactions with } \\
\text { cooperative premises (in thous. pcs.) }\end{array}$ & 490 & 471 & 409 & 452 & 452 & 428 \\
\hline $\begin{array}{l}\text { (Total) Number of transactions without } \\
\text { cooperative premises (in thous. pcs.).) }\end{array}$ & 427 & 410 & 358 & 397 & 402 & 383 \\
\hline $\begin{array}{l}\text { (Total) Dynamic number of transactions } \\
\text { without cooperative premises }(\%)\end{array}$ & & $96 \%$ & $87 \%$ & $111 \%$ & $100 \%$ & $95 \%$ \\
\hline Number of CSO transactions (in thous. pcs.) & 306 & 277 & 208 & 257 & 285 & 324 \\
\hline Dynamic number of CSO transactions (\%) & & $91 \%$ & $75 \%$ & $124 \%$ & $111 \%$ & $114 \%$ \\
\hline $\begin{array}{l}\text { Share of CSO transactions of total turnover } \\
\text { (without cooperative premises) }\end{array}$ & 0.72 & 0.68 & 0.58 & 0.65 & 0.71 & 0.85 \\
\hline $\begin{array}{l}\text { Number of CSO ownership transactions } \\
\text { (in thous. pcs.) }\end{array}$ & 121 & 133 & 150 & 140 & 117 & 59 \\
\hline Number of transactions (in thous. pcs.) & 63 & 61 & 51 & 55 & 50 & 45 \\
\hline $\begin{array}{l}\text { Vulnerability research GUS in terms of the } \\
\text { number of transactions regarding ownership } \\
\text { incl. cooperative premises (in thous. pcs.) }\end{array}$ & 184 & 194 & 201 & 195 & 167 & 104 \\
\hline Value CSO (in billion PLN) & 44,036 & 46,934 & 31,902 & 33,567 & 48,803 & 71,051 \\
\hline Dynamic value CSO (\%) & & $107 \%$ & $68 \%$ & $105 \%$ & $145 \%$ & $146 \%$ \\
\hline
\end{tabular}

Source: Own study based on: KAŁKOWSKI, 2010, p. 12 and 19 and REAL ESTATE TURNOVER IN 2012 p.17.

Despite the absence of a simple relationship between the number and value of transactions, the analysis shows that the $45+\%$ annual real estate growth rate recorded by the CSO for 2011-2012 can hardly be referred to as credible. At the same time, the CSO's results fairly reliably reflect market trends in the years 2003 - 2009, including the cycle of demand for those years. During this period, very strong ties were noted between the changing situation on the market and the macroeconomic situation of the economy, including GDP growth, corporate investment, and an increase in the availability of credit and the lowering of the cost of these loans (KONOWALCZUK, RAMIAN, ŚMIETANA 2013, pp. 403418 ). In 2010-2012, there were no similar economic circumstances, thus indicating the possibility of the beginning of the next cycle of demand and therefore justifying the large growth in the value of these transactions, is not credible. In addition, there were no significant changes made to the structure of the real estate market. It is for this reason that conducting a thorough and comprehensive analysis of the research methodology used by the CSO was necessary - for three typical stages of market research relating to: (1) research methodology (design), (2) the conditions of implementation, and (3) the manner of publication (communication) of the study (MARKET STUDY. 2005, p. 27).

It should be noted that the CSO reports include a warning regarding the "relative nature of the data," which in practice means very little comparability between the periods due to the technical and organizational problems involved in collecting the obligatory statistical data. This is confirmed by the results of the analysis presented in Table 1 . These results show deterioration in the effectiveness of the survey (the share of transactions within the survey) in 2007-2009, from 0.72 to 0.58 , and a gradual improvement over the following three years, from 0.65 to 0.85 . The CSOs research gap since 2009 has been greatly reduced, but in 2012 it was still 15\%, translating into approximately 59,000 transactions being statistically "lost". Taking into account the fact that cooperative premises were not covered in the M-04s, the gap was still large and included the 104,000 sales transactions in 2012. Therefore, the "mystery" of strong market growth post-2010, as reported by the CSO, can be explained primarily by the improved effectiveness of the CSO survey for the years 2011-2012, coinciding with the introduction of the standard electronic transmission of statistical data in 2010.

This paper assumes that theoretical valuation will be conducted from the perspective of an economic model allowing for a breakdown by the classic triad of economic entities: households, businesses (enterprises) and the state (the regulatory aspect). Of these entities, the problems concerning the valuation of enterprises are addressed in particular. This is justified owing to their significance and function in the economy. Literature emphasizes that businesses, unlike households and the state, have the ability to create income and multiply capital (HICKS 1975, p. 146-147). In 
addition, adopting the perspective of the substantive classification of property (including physical, location and functional characteristics) and the intentional focus on the issues of recognition in the official statistics of the functioning CRE market, is justified in so far as it is a subject-area rarely addressed in national literature. The substantive classification approach using legal criteria and their economic functions is dominant. Apart from the segment of standard commercial real estate and property development, research into the CRE market is approached only parenthetically. This may also be related to the weak exposition of this real estate segment in public statistics, leading to a lack of sufficient access to market data. This, in turn, may form a limitation in conducting empirical research, and impede access to information for investors, thereby deepening the problem of the low effectiveness of this market segment.

\section{Basic characteristics of CSO methodology}

The framework of this article allows the theoretical section to provide only a basic critique of the methodological assumptions of the CSO. The analysis is based on the descriptions of methodology contained in CSO annual reports. An assessment of the M-04s statistical report sheets was also performed, with a detailed analysis carried out on data from the years 2004, 2006, 2009 and 2012; however, there is no formal M-04s sheet for 2012 as the electronic transmission of data was introduced in 2010 .

CSO research is based on secondary, processed data collected in the real estate cadastre. The cadastre is held at the poviat office where background information regarding real estate is collected in the form of deeds, trade transactions, source evidence regarding changes in ownership and real estate proprietors, as well as other source documents relating to, e.g. real estate divisions, expropriations, changes of the legal status of the real estate, both juridical and administrative. In accordance with legal regulations, the function of the cadastre continues to hold full registers of land and buildings. The manner in which it functioned in the analyzed period was determined by the regulation of the Minister of Regional Development and Construction dated 29 March 2001 from the register of land and buildings (ACT of 2001). How M-04s statistical reports are prepared is limited to the organization and scope of data collected in the real estate cadastre. This cadastre also includes documentation of real estate transactions taking place outside the form of notarial deeds, relating to, for example, the judicial termination of ownership or the enforcement of property sales, and conducted on behalf of the trustee or expropriation on the basis of administrative decisions. The scale of this type of transaction has not, as yet, been officially evidenced in Poland both with regard to the number or size of these markets (KONOWALCZUK 2009a, p. 63). Transactions made outside of notarial acts are not covered by the M- 04s reports, which means that a significant part of the turnover is beyond the scope of accounting in the context of public statistics and other basic market studies (e.g. 23 years Polish real estate market in 2013, p.5 ). This is a significant design flaw of the entire system, which also applies to the market of tradable rights to premises other than ownership. For example, in KA£KOWSKI 2010, p.7., Based on the author's own research, it is estimated that in terms of the voivodeship of Silesia, the CSO fails to address in its studies from 30 to $60 \%$ of real estate transactions within the local markets.

Data in M-04 reports is collected in a comprehensive manner on three levels (planes). The first two relate to the substantive and ownership criteria of the property, and the third involves a description of the terms of the transaction. The ownership approach to a property is dominant, and a framework for classification has been determined in the context of legal characteristics, while characteristics of the real estate as things have been expressed by including the property's usage and location.

The data collected in the M-04 report relate to:

1) Characteristics of the traded entity, with different types of real estate identified by legal criteria and usage, as well as by the degree of urbanization (substantive approach);

2) The nature of the entity entitled to the ownership of the property, limited to indicating one type of business, i.e., cooperative housing (ownership approach);

3) Market conditions of the sales agreement.

\subsection{Substantive criteria}

The CSO divides real estate into four categories:

1) Commercial, having ownership of the premises on the property;

2) Buildings, including the right of ownership to buildings being distinct properties;

3) Developed properties, including land ownership and perpetual usufruct; 
4) Land real estate (undeveloped), including land and perpetual usufruct as owned entities.

Buildings as separate items of property are presented in section 2 of the M-04 report, as a group of "buildings" or "real estate properties". The assessment indicates that there is no economic basis or formal need to maintain separate analyses for section 2. One hypothesis suggests a possible waiver of this section in the M-04s and market reports, or the inclusion of this group for the purpose of analysis in the developed land or perpetual usufruct category. This results from both a theoretical assessment as well as telephone and personal surveys conducted with individuals responsible for carrying out Registers of Real Estate Prices and Values in poviat offices. Despite incidental transactions related to the adjustment of the land's legal status, it may be assumed that a group of buildings on a property which are legally separate properties can be traded only if the buyer has perpetual usufruct of the land. In situations such as this, information regarding transaction should be added to section 4 , in the "Type of legal right to the land: perpetual usufruct" column.

All respondents in the pilot study agreed with this proposal. Entries of transactions involving buildings from three townships for which the CSO showed the highest transaction-count were studied in detail (REAL ESTATE TURNOVER IN 2012, 2013, p.75). This study took the form of a telephone interview and covered gminas (communes) in the poviats (districts) of Pszczyna, Bierun-Lędziny and Ruda Sląska. It was found that the transactions included in this group occurred as a result of misinterpretation by data input operators. Only in the case of the Bierun-Lędziny area were several specific transactions relating to the regulation of the legal status of garages considered appropriate to remain in this group. In the remaining two cases, the poviats of Myslowice and Częstochowa (selected randomly) took individual surveys, and the same conclusions were reached, i.e. this category of classification was deemed superfluous. Building transactions can be entered into section 4 .

For the purpose of CSO research, it is proposed that real estate be divided into three categories:

1) Premises including ownership of the property;

2) Developed land, with perpetual usufruct and ownership of land included;

3) Undeveloped land, with perpetual usufruct and ownership of land included.

CSO research takes into account the geodetic state of the land through the types of land use and type of building (function) and premises. The state of agricultural land may not correspond to its economic utility, and thus the purpose of the sale transaction, which is closely linked to the property's socio-economic purpose. Therefore, market research should ultimately include not only the formal classification of the land (in accordance with records), but also the manner in which it is actually used and its potential, which is related to the possibility of making changes to the existing planning documents. As a result, it should be mandatory to include this type of information in notarial deeds and M-04 documents. This would require changes to the M-04s document in terms of data regarding the types of uses for undeveloped land zoned for development. The current classification results in the "other" category including over $80 \%$ of transactions in terms of number and value. In order to enable the economic analysis of a market estimated to be worth approximately 5,000 million PLN/year, additional types of land categories would need to be introduced.

The manner in which data regarding developed real estate is collected and presented needs to be supplemented. This issue concerns the presentation of the results of the CSO's analyses only in respect to the "registered area of real estate", i.e. the area of the land. In practice, the conversion unit used by investors on the market is the price/value of $1 \mathrm{~m}^{2}$ of usable floor space. Thus, with the addition of data from the cadastre of buildings, it will ultimately be necessary to supplement the analysis with unit prices converted to the usable surface area of buildings and introduce of a larger number of property types to the analysis. Currently, developed land is divided into three (by type of development) categories of buildings: residential, homestead (with storage buildings), and other. In the case of residential buildings, providing a breakdown into single- and multi-family houses would be justified. For buildings in the "other" category, it would be necessary to introduce distribution by type of building. The minimum range of disaggregation in the "other" group should include the criteria used in the M-04s regarding the types of premises (retail/service, office, manufacturing, garages, etc.), with the necessity of adding storage buildings to the list.

Earlier research regarding the industrial property market showed that the range of geodetic datum recorded is too narrow and formally linked to the legal definition of land use and industrial buildings, which is in essence different from its economic classification (KONOWALCZUK, RAMIAN, ŚMIETANA, 2011, p.159). It is for this reason that CSO research does not indicate the actual scale of turnover on 
these markets. The optimal solution would be to classify buildings according to the requirements of the Classification of Fixed Assets (CFA) (Act of 26 January 2010 ) taking into account information such as their age in the survey data. It should be noted that CSO research included three age criteria for buildings: built prior to 1939, between 1939 and 2000, and since 2001 (Real estate in 2006, 2007, pp. 44$45)$.

\subsection{Ownership criteria}

Recognition of real estate by ownership criteria appears parenthetically in CSO research when separating turnover conducted by housing cooperatives in section 2 of the M-04s report from 2006. However, there are no results of any analysis in the CSO report for that year. The evaluation of the CSO survey does not take into account the ownership classification of real estate. However, the real estate cadastre includes functionality with regards to the recognition of the classification of property rights in separate groups and sub-groups, including the legal form of a company's registration (cf. §. 17 and 18 ACT of 2001). The real estate cadastre together with data from the notarial deed allow for their introduction into CSO research using the classification of groups and registered sub-groups in the records. The problematic issues lie with companies that are run by natural persons (individuals), because subgroup 8.2 links companies with homesteads on agricultural land. These are only regarded as separate in the subset of 8.1. There are no research opportunities in terms of the industry (scope and range of business activities), the exception being agricultural land holdings. Missing, are activities conducted in legal forms other than farms, such as cooperatives or partnerships. The real estate cadastre and the scope of information contained in notarial deeds allows basic CSO research to include separate corporate real estate market analyses. This, however, requires the addition of substantive criteria to the format of the MS-04s, distinguishing between companies on the basis of the total turnover into the M-04s reporting format for selected groups (and subgroups), and registered owners (and proprietors). Proposing changes in this field requires in-depth study, and this is indeed difficult due to there not being a legal, comprehensive and inclusive definition of an enterprise, which could be used for the universal identification of enterprises.

\subsection{Transaction terms and report contents}

The general division of the M-04s report and CSO market reports regarding the conditions of an agreement includes criteria as to the manner in which the buyer is identified by the seller of the property. Three types of transactions are identified:

1) on the open market with an additional division into primary and secondary markets,

2) as a result of auction,

3) as a result of non-auction sales,

Indeed this is not a form of legal turnover, only a manner in which the buyer is identified, hence the term may seem inadequate. In addition, another type of transaction does occur in practice - "other unidentified," which is consistent with the M-04s report (2004 and 2006). Based on this data, the CSO established a group of market transactions by including "both those in which the sale occurs by equivalent exchange, corporate (private and council) accommodation sold at preferential prices, as well as land leased for 15-25\% of the value, "(TRANSAKCJE KUPNA/SPRZEDAŻY NIERUCHOMOŚCI W 2004, p.5). Other non-market transactions are not included in analyses. This is particularly applicable to gratuitous contracts such as donations and other agreements including life estates or tenancy, or established property rights.

The manner in which the CSO segments different types of transactions is essentially correct, particularly when taking into account the great importance of the specific rules of managing the property of the Treasury and local governments (with their specialized agencies), state-owned enterprises, and the specific partnerships with the Treasury and local governments in Poland. The principle of sale by auction functions for such properties. An exception, as indicated in legislation, is a non-auction sale. "Free market" sales take place only incidentally. In the case of these entities, it is obligatory for the notarial deed to contain information regarding the form of turnover. For the remaining entities (households and companies other than the specific partnerships with the Treasury and local government), there is no legal duty to disclose, in the notarial deed, neither the manner in which the purchaser was identified, nor the form of the sale. Therefore, any limitations may result only from internal regulation (e.g., partnership agreements, the rules of the sale in a cooperative). It is for this reason that notarial deeds lack full information regarding the actual form of sale, i.e. whether 
an auction was, in fact, organized. In the absence of criteria determining the conditions that need to be met in order for certain actions to be considered particular forms of sale, this becomes problematic.

An important unresolved issue in practice is that of prices disclosed for the purposes of the CSO. The first problem concerns allowances and discounts resulting in transaction prices differing significantly from the market value. The second, more important issue relates to VAT. Survey research in this field allowed only for the existence of this problem to be identified. What is lacking in this area is a clear methodology. Owing to the different ways in which information in notarial deeds can be disclosed by parties, this lack of clear methodology can result in the distortion of market data in COS research. In this regard, a clear CSO solution is required. The author advocates the adoption of a uniform basis with regards to prices without VAT (net prices), as it is in real estate valuation and appraisal.

The additional segmentation of the "free market" group of transactions into primary and secondary markets in CSO research has proven valuable. However, it seems that there is no justification for the use of this criterion solely for this form of turnover. The primary market, according to M-04s clarification, refers to "... property, whose date and time of first use is not further than two reporting periods." This refers both to developer transactions (buildings opened for use) as well as new buildings on the secondary market. The fact that developer real estate is not a clear and separate option significantly impedes the analysis of the CRE market, which is highly sensitive to changes in economic fluctuations. The most straightforward and reasonable solution would be the introduction of a separate criterion of "developer real estate." The term "primary market" should be reserved for this type of transaction, because this is the context in which it is now used. The remaining transactions relate to the secondary market, which could be divided into age groups with the first group of "new buildings" also including those which are up to 5 years old (from date of completion to date of use).

Between 2003 and 2008, the CSO annual report was called "Purchase/sale transactions," which was adequate to the actual scope of research. Since 2009, the title of the report has been "Real estate turnover," which in actual fact, does not correspond to its content as it still applies only to transactions regarding the sale of real estate ownership. Therefore, the lack of recognition of transactions other than sales in CSO analyses, where notarial statistical reports (MS-Not 24) distinguish 45 different types of contracts in the form of notarial deeds, needs to be addressed. Of these 45 types of contracts, 35 concerned what can be broadly referred to as real estate turnover. Systematic research regarding the number of contracts on the real estate market has been collected on the basis of the CSO report (23 years of the Polish real estate market 2013, p.10 and 27). Dominant in this report (MS-Not 24) are the substantive and legal approach to real estate, and only the Treasury and local governments are distinguished in terms of ownership rights. In addition to the lack of recognition of the ownership rights of companies, another drawback is the fact that the report only records the number of notarial deeds for the various forms of turnover and types of property.

\section{Comparison of selected CSO data with the database of appraisers and valuers}

\subsection{Scope of research}

Research presenting a comparison of the basic parameters of the real estate market in the Silesian voivodeship for 2012 was formed on the basis of information in two databases. The information presented in the annual reports of the Central Statistical Office (CSO Data - CSO Database) was compared to the results of the analysis of data collected in a database of appraisers and valuers (AV Data - AV Database). The market parameters adopted for comparison were, in both cases, based on the same source information obtained from notarial deeds regarding sales.

The AV database is unique as it was established for the sole purpose of determining market value. It determines both the extent of market information collected and the degree of detail. It was created to counter-measure the lack of access to public information regarding real estate sales transactions at the time. This analysis program is dated 1997-1998, when it started to be used for market analyses; in Poland, it was first applied by the the Silesian Association of Valuers. Currently, there are more than a dozen autonomous local databases with large information resources available (KRZEMPEK 2010). Defining the concept of a real estate market transaction for the Partner database is different from the conditions for CSO research, as in addition to the provision of equivalence, transaction conditions are also taken into account. 


\subsection{Results of database comparison between CSO and AV}

Table 2 presents the results of the comparison of CSO and AV databases for the market of the Silesian voivodeship in 2012.

Table 2

Comparison of CSO and AV data for selected real estate markets in the Silesian voivodeship

\begin{tabular}{|c|c|c|c|c|c|c|c|}
\hline \multirow[b]{2}{*}{ Lp. } & \multirow[b]{2}{*}{ Type of real estate } & \multirow[b]{2}{*}{ Criterion and unit } & \multirow[b]{2}{*}{$\begin{array}{l}\mathrm{CSO} \\
\text { data }\end{array}$} & \multirow[b]{2}{*}{$\begin{array}{l}\mathrm{AV} \\
\text { data }\end{array}$} & \multicolumn{2}{|c|}{ Average } & \multirow[b]{2}{*}{$\begin{array}{c}\text { Completeness } \\
\text { AV data }\end{array}$} \\
\hline & & & & & $\begin{array}{l}\text { CSO } \\
\text { data }\end{array}$ & $\begin{array}{l}\text { Aave } \\
\text { data }\end{array}$ & \\
\hline \multirow{3}{*}{1.} & \multirow{3}{*}{$\begin{array}{l}\text { Housing } \\
\text { premises }\end{array}$} & Number of transactions & 11,721 & 8,644 & & & $74 \%$ \\
\hline & & Area $\left[\mathrm{m}^{2}\right]$ & 614,483 & 460,861 & 52 & 53 & $75 \%$ \\
\hline & & Value ['000. PLN] & $1,442,539$ & $1,250,799$ & 123 & 145 & $87 \%$ \\
\hline \multirow{3}{*}{2.} & \multirow{3}{*}{$\begin{array}{c}\text { Non-housing } \\
\text { premises }\end{array}$} & Number of transactions & 1,180 & 1,140 & & & $97 \%$ \\
\hline & & Area $\left[\mathrm{m}^{2}\right]$ & 69,911 & 71,906 & 59 & 63 & $103 \%$ \\
\hline & & Value [’000. PLN] & 99,030 & 85,353 & 84 & 75 & $86 \%$ \\
\hline \multirow{3}{*}{3.} & \multirow{3}{*}{ Total premises } & Number of transactions & 12,901 & 9,784 & & & $76 \%$ \\
\hline & & Area $\left[m^{2}\right]$ & 684,394 & 532,767 & 53 & 54 & $78 \%$ \\
\hline & & Value ['000. PLN] & $1,541,569$ & $1,336,152$ & 119 & 137 & $87 \%$ \\
\hline \multirow{3}{*}{4.} & \multirow{3}{*}{ Buildings } & Number of transactions & 160 & 0 & & & \\
\hline & & Area & 57,165 & 0 & 357 & & \\
\hline & & Value ['0 & 44,744 & 0 & 280 & & \\
\hline \multirow{3}{*}{5.} & \multirow{3}{*}{$\begin{array}{c}\text { Developed } \\
\text { w. housing and } \\
\text { homestead }+ \\
\text { storage }\end{array}$} & Number of Transactions & 5,283 & 3,266 & & & $62 \%$ \\
\hline & & Area $\left[\mathrm{m}^{2}\right]$ & 29,725051 & $5,425,463$ & 5,627 & 1,661 & $18 \%$ \\
\hline & & Value [’000 PLN] & $1,313,804$ & $1,043,362$ & 249 & 319 & $79 \%$ \\
\hline \multirow{3}{*}{6.} & \multirow{3}{*}{ Other developed } & Number of Transactions & 1,801 & 1,383 & & & $77 \%$ \\
\hline & & Are & $6,233,223$ & $4,071,049$ & 3,461 & 2,944 & $65 \%$ \\
\hline & & Value [ & $1,180,115$ & 897,034 & 655 & 649 & $76 \%$ \\
\hline \multirow{3}{*}{7.} & \multirow{3}{*}{ Total developed } & Number of $\mathrm{t}$ & 7,084 & 4,649 & & & $66 \%$ \\
\hline & & Area & $35,958,274$ & $9,496,512$ & 5,076 & 2,043 & $26 \%$ \\
\hline & & Value [ & $2,493,919$ & $1,940,396$ & 352 & 417 & $78 \%$ \\
\hline \multirow{3}{*}{8.} & & Number of & 699 & 4,755 & & & $680 \%$ \\
\hline & Land $\mathrm{f}$ & Are & $1,327,537$ & $11,171,250$ & 1,899 & 2,349 & $842 \%$ \\
\hline & & Value & 68,552 & 413,505 & 98 & 87 & $603 \%$ \\
\hline & Land & Number of $\mathrm{T}_{1}$ & 17 & 201 & & & $1,182 \%$ \\
\hline 9. & & Are & 78,140 & $1,293,300$ & 4,596 & 6,434 & $1,655 \%$ \\
\hline & & Value [ & & 85,204 & 370 & 424 & $1,356 \%$ \\
\hline & & Number of & & 637 & & & $20 \%$ \\
\hline 10. & & Are & $8,520,730$ & $2,490,591$ & 2,664 & 3,910 & $29 \%$ \\
\hline & & $\begin{array}{l}\text { Value [ } \\
\end{array}$ & 607,722 & 147,826 & 190 & 232 & $24 \%$ \\
\hline & & Number of $T_{1}$ & 3,915 & 5,593 & & & $143 \%$ \\
\hline 11. & Total & Area $\left[m^{2}\right]$ & $9,926,407$ & $14,955,141$ & 2,535 & 2,674 & $151 \%$ \\
\hline & & Value [' & 682,559 & 646,535 & 174 & 116 & $95 \%$ \\
\hline & & Number o & 6,128 & 1,892 & & & $31 \%$ \\
\hline 12. & $\begin{array}{l}\text { Agricl } \\
\text { forect }\end{array}$ & Arec & $55,897,657$ & $32,517,479$ & 9,122 & 17187 & $58 \%$ \\
\hline & & Value [ & 735,884 & 72,270 & 120 & 38 & $10 \%$ \\
\hline & & Number of Transactic & 0 & 1,897 & & & \\
\hline 13. & Other real estate & Are & 0 & $4,593,404$ & & 158 & \\
\hline & & Value [ & 0 & 298,819 & & 2,421 & \\
\hline & Total & Number o & 128 & 3,789 & & & $62 \%$ \\
\hline 14. & agric & Arec & $55,897,657$ & $32,816,298$ & 9,122 & 8,661 & $59 \%$ \\
\hline & & lue [ & 735,884 & 371,089 & 120 & 98 & $50 \%$ \\
\hline 15 & & Number of Transactions & 30,188 & 23,815 & & & $79 \%$ \\
\hline (1) & $\operatorname{tra}$ & & $02,523,897$ & $57,800,718$ & 3,396 & 2,427 & $56 \%$ \\
\hline & region & Value ['000 PLN] & $5,498,675$ & $4,294,172$ & 182 & 180 & $78 \%$ \\
\hline
\end{tabular}

Source: Own study.

The comparison illustrates an incomplete AV database, which is only in part due to the different scope of the study (exclusion from the AV database of non-equivalent price sale transactions). The incomplete AV database stems from organizational problems and a lack of systemwide comparability allowing immediate comparison of its completeness. Assuming that approximately $10 \%$ of sales are recognized as being non-market-based in the AV database, it has a high (approximately 90\%) completion in terms of number and value. The low completeness on the surface is associated with a 
deficit of transactions regarding non-urbanized property, which is generally not a significant limitation in CRE market research, except for market farms.

The AV database relates to issues of valuation, hence it should be possible to identify the characteristics of the real estate market, and therefore to find an explanation for the different transaction prices. Owing to the very high (over 70\%) deficiencies relating to the disclosure of survey data (on land type and building function), the manner in which a property is used is identified in the $\mathrm{AV}$ database using remaining information found in notarial deeds. For developed properties, it is essential to introduce a detailed description of the building's function-type, and for land - purpose in the local zoning plan or based on other planning documents. The AV database also clearly shows the parties to the transaction (the legal form of the entity), which means it is possible to test the market by ownership criteria of CRE.

The advantage of the AV database lies in its ability to better identify the economic nature of real estate for dynamic land markets, such as residential land markets (more than 6-fold better identification), and the CRE market of industrial land and other land. The description of real estate characteristics in the AV database is essentially limited to the information contained in the notarial deed, supplemented to a limited extent with data from public documents, such as local plans. Overall, the AV database allows for a better manner of collecting data, as it takes into account more aspects of the property on the basis of which it is possible to perform multifaceted market research, including in terms of ownership and specific divisions for CRE. CSO data does not allow for this kind of research, and the data is satisfactory only in relation to the market analysis of premises, with the very important segment of cooperative units omitted. The database used to assess the CSO was found to be incomplete. However, the database created on the reports of notaries for the needs of the Ministry of Justice has been assessed as the only complete database of public databases which gather information regarding the number of transactions from the basic division of real estate. Using this background information, it is possible to assesses the $\mathrm{AV}$ database after performing a series of tedious adaptations necessary to ensure comparability with that of the CSO. CSO data was in agreement as to the number and size of transactions. However, with regards to value, the discrepancy reached 12.5 million PLN $(0.2 \%$ of the total market). In order to verify the pooled data from the region, additional assessments for selected local markets (poviats) listed in the CSO survey (Real estate in 2012, 2013) as being the most active markets, were performed. These results are not presented due to their sheer volume. Nevertheless, they confirmed the findings on the basis of data provided for the entire voivodeship.

\section{Conclusions}

The results of these theoretical considerations, the analysis of literature and empirical studies allow for the following conclusions to be drawn:

1) Based on data collected by the Central Statistical Office alone, is not currently possible to perform research on CRE markets. The organization of real estate cadastres and data contained in notarial deeds allows the CSO to conduct studies on the real estate market in substantive terms only following significant changes to the information collected regarding the parties of the sales agreement.

2) In addition, to enable comprehensive research into the CRE market, changes in the classification of properties used for research purposes are also necessary, and land use should also be considered. In addition to ceasing to recognize separate categories of buildings, changes to the criteria, identified by isolating types of real estate, and changes in the description of the manner in which agreements are concluded, are also necessary. The CSO database does not resolve the issue of the collection of statistics regarding prices from the perspective of VAT and applicable discounts.

3) Despite significant improvements in 2010-2012, the CSO database is still not complete. In 2012, there was still a $15 \%$ shortage in relation to the number of sales transactions. CSO surveys should be considered incomplete due to a system error causing the exclusion of transactions made outside the form of notarial deeds and the exclusion of co-operative premises. Changes in this area can be achieved only through significant regulatory change.

4) Despite the fact that approximately $10 \%$ of the AV database is incomplete (in comparison to the CSO database), it allows research to be performed on the CRE market pertaining to the identification of the legal form of the parties to the sale agreement. Furthermore, the method of 
collecting data on a property based on the data contained in the notarial deed allows for a clearer identification of the economic utility (market characteristics) of a property. This is confirmed by the results of comparisons on the residential and industrial land markets, and research on local markets in terms of developed industrial estates. The AV database clearly distinguishes price from the point of view of the VAT and excludes price reductions.

5) Additional research which has not been covered in the present paper is required - issues relating to the turnover of large and unique CREs and the manner in which developers and investment markets function, as well as the manner in which the growing market of investment funds is referred to and included in analysis.

\section{References}

KęDZIOR Z., 2005, (red. )Badania rynku. Metody i zastosowania, 2005. Wyd. PWE, Warszawa. (Market study. Methods and applications)

FURGA J., 2013, Tworzenie baz danych o nieruchomościach oraz modeli oceny wartości zabezpieczenia na nieruchomości $\mathrm{w}$ oparciu o nowe wymogi Rekomendacji J, http://www.ehipoteka.pl/ehipoteka/Szkolenia-i-konferencje/Szkolenia/18.11.2013-r. (Creating databases of property and assessment models for real estate collateral value based on the new requirements of recommendation)

HICKS J.R., 1975. Wartość i kapitał. PWN, Warszawa. (Value and capital)

KAŁKOWSKI L., 2010, (main autor) i Co-autors: Dudek j, Sroczyński A., Rydzik, Wierzchowski M.W., 20 LAT POLSKIEGO RYNKU NIERUCHOMOŚCI. Monitoring za lata 1990-2009. Instytut Rozwoju Miast Kraków. http://irm.krakow.pl/pl/do_pobrania.html (20 years of the Polish real estate market)

KONOWALCZUK J.,2009, Wycena nieruchomości przedsiębiorstw. Wyd. CH Beck, Warszawa. (Corporate real estate valuations)

KONOWALCZUK J., 2009a, Ocena przydatności dotychczasowych badań rynku nieruchomości w Polsce do badania rynku nieruchomości przemystowych $[\mathrm{w}]$ Nieruchomości przemystowe a rynek. Diagnoza stanu i perspektywy rozwoju na Ślasku. (Badania statutowe). Kierownik projektu: H. Henzel, członkowie zespołu: J. Konowalczuk, T. Ramian, K. Śmietana, E. Zagórska, maszynopis niepublikowany. Akademia Ekonomiczna im. Karola Adamieckiego w Katowicach. (Evaluation of the utility of existing real estate market research in Poland for research into corporate real estate, Corporate real estate and the market. A diagnosis of the condition and perspective for development in Silesia)

KonOWALCZUK J., 2011, Źródta informacji o rynku nieruchomości w Polsce [w] Bariery informacyjne rozwoju rynku nieruchomości. Polska na tle wybranych krajów (Badania statutowe). Kierownik projektu: H. Henzel, członkowie zespołu: J. Konowalczuk, T. Ramian, K. Śmietana, E. Zagórska, M. Wilczek, A. Maszczyk, T Bolek. maszynopis niepublikowany. Uniwersytet Ekonomiczny w Katowicach. (Sources of information about the real estate market in Poland)

KONOWALCZUK J., RAMIAN T., ŚMIETANA K., 2011, Ocena stanu dotychczasowych badań transakcji sprzedaży nieruchomości przemystowych w Polsce [w] Stan i tendencje rozwojowe rynku nieruchomości, red. nauk. H. Gawron. Wydawnictwo Uniwersytetu Ekonomicznego w Poznaniu, Poznań 2011, s. 159. (Evaluation of the conditions of existing studies with regards to research into the sale transaction of corporate real estate in Poland.

KONOWALCZUK J., RAMIAN T., ŚMIETANA K., 2013, Rynek gruntów przedsiębiorstw w województwie ślaskim na tle zmian koniunkturalnych w gospodarce. W: Rynek nieruchomości. Finansowanie rozwoju miast. Red. nauk. M. Bryx. Wydawnictwo CeDeWu, Warszawa. (The market of corporate real estate land in the Silesian voivodeship on the background of economic change)

KUCHARSKA-STASIAK E.,2006, Nieruchomość w gospodarce rynkowej. PWN, Warszawa. (Real Estate in the market economy)

KRZEMPEK J., 2010, Raport $z$ badania stan baz danych w Polsce. Nieruchomość 4/2010. ŚSRM, Katowice. (Report from the testing of the state of data bases in Poland)

TRANSAKCJE KUPNA/SPRZEDAŻY NIERUCHOMOŚCI W 2004 r., 2005. Notatka informacyjna. Wyniki badań GUS, Warszawa. (Real estate purchase/sales transactions in 2004)

OBRÓT NIERUCHOMOŚCIAMI W 2006 r., 2007. Informacje i opracowania statystyczne, GUS, Warszawa. http://www.stat.gov.pl/gus/5840_1120_PLK_HTML.htm (Real estate turnover in 2006)

OBRÓT NIERUCHOMOŚCIAMI W 2009 r., 2010. Informacje i opracowania statystyczne, GUS, Warszawa. http://www.stat.gov.pl/gus/5840_1120_PLK_HTML.htm (Real estate turnover in 2009)

OBRÓT NIERUCHOMOŚCIAMI W 2012 r., 2013. Informacje i opracowania statystyczne, GUS, Warszawa. 
http://www.stat.gov.pl/gus/5840_1120_PLK_HTML.htm (Real estate turnover in 2012)

23 LATA POLSKIEGO RYNKU NIERUCHOMOŚCI. Monitoring za lata 1990-2012. 2013. Instytut Rozwoju Miast Kraków. http://irm.krakow.pl/uploadUser/file/Monitoring_2013.pdf (23 years of the Polish real estate market)

DYREKTYWA nr 2007/2/WE ustanawiającej infrastrukturę informacji przestrzennej we Wspólnocie , Dz. Urz. UE L 108 z 25.04.2007, „INfrastructure for SPatial InfoRmation in Europe” (INSPIRE) Journal of Laws, 2007, No. 108,) (Directive nr 2007/2/WE establishing an infrastructure for spatial information in the Community)

ROZPORZĄDZENIE 2001 Ministra Rozwoju Regionalnego i Budownictwa z dnia 29 marca 2001 r. $w$ sprawie ewidencji gruntów i budynków, Dz. U. 2001 nr 38, poz.454), (Directive 2001 of the Minister for Regional Development and Construction from 29 March 2001, regarding the registration of land and buildings, Journal of Laws, 2001, No.38, item 454)

ROZPORZĄDZENIE Ministra Administracji i Cyfryzacji z dnia 29.11.2013 r. zmieniajace rozporzadzenie w sprawie ewidencji gruntów i budynków, Dz.U. 2013 r. poz. 1551. (Directive 2013 of the Minister for Administration and Digitisation from 29.11.2013, the changing direcive for the registration of land and buildings, Journal of Laws 2013 item 1551)

ROZPORZĄDZENIE 2010 Rady Ministrów z dnia 10.12.2010 r. w sprawie Klasyfikacji Środków Trwałych (KŚT), Dz. U. z 2010 r. nr 242, poz. 1622) (Directove 2010 of the Council of Ministers) dated 10.12.2010, regarding the Classification of Fixed Assets, Journal of Laws, 2010, no.242, item 1622). 